\title{
Embedment strength of steel dowel in wood specimens according to ABNT NBR 7190:1997 and ASTM D5764: 2007 Standards
}

\author{
Resistencia al aplastamiento de pernos de acero en cuerpos de prueba de madera \\ de acuerdo con las normas técnicas ABNT NBR 7190:1997 y ASTM D5764:2007
}

\author{
Julio Cesar Molina $^{1 *} \quad$ Diego Rodrigues de Oliveira $^{1} \quad$ Murilo Negreli $^{1}$ \\ Ernesto Abel Fernando Friedmann Pallarolas ${ }^{1}$
}

Recibido 15 de marzo de 2016, aceptado 25 de julio de 2016

Received: March 15, 2016 Accepted: July 25, 2016

\begin{abstract}
The aim of this work was the study of embedment strength of dowels in reforested wood pieces. Analytical and experimental approaches were considered. Specimens for testing were made of Pinus elliottii (C30) and Eucalyptus saligna (C50) wood with steel rods with diameter of $6.35 \mathrm{~mm}(1 / 4$ "). The tests were performed according to the recommendations of ABNT NBR 7190:1997 and ASTM D5764:2007 Standards with subsequent comparison between the analytical and experimental results for embedment strength in the parallel and perpendicular directions to the grain. The results showed that the analytical and experimental values for embedment strength according to American Standard presented closer to each other compared to the Brazilian Standard in this case. Moreover, the American Standard recommended test specimen dimensions, which facilitate the manufacture, especially in the direction perpendicular the to wood fibers.
\end{abstract}

Keywords: Standardization, experimental tests, analytical models.

\section{RESUMEN}

El objetivo de este trabajo fue estudiar la resistencia al aplastamiento de pernos de acero en cuerpos de pruebas de madera de reforestación. Dos enfoques principales han sido considerados: analítico y experimental. Las muestras para los ensayos estaban hechas de madera de Pinus elliottii (C30) y Eucalyptus saligna (C50) y los pernos de acero común con 6,35 mm (1/4") de diámetro. Los ensayos se realizaron de acuerdo con las recomendaciones de las normas ABNT NBR 7190:1997 y ASTM D5764:2007 con posterior comparación entre los resultados analíticos y experimentales, que se obtuvieron para las resistencias al aplastamiento en las direcciones paralela y perpendicular a las fibras de la madera. Los resultados mostraron que los valores analíticos y experimentales obtenidos para la resistencia al aplastamiento de acuerdo con la norma técnica americana, se mostraron menos dispersos entre sí en comparación con los de la norma brasileña. Además, la norma técnica americana recomienda dimensiones para los cuerpos de prueba que hace que sean más fáciles de ser fabricados, principalmente en los cuerpos de dirección normal a las fibras de la madera.

Palabras clave: Normalización, análisis experimental, modelos analíticos.

\footnotetext{
1 Faculdade de Engenharia Industrial Madeireira. Universidade Estadual Paulista Julio de Mesquita Filho. Rua Geraldo Alckmin 519. Vila N. Sra. de Fátima. CEP 18409-010. Itapeva, SP, Brasil.

E-mail: molina@itapeva.unesp.br; diego.rodrigues@grad.itapeva.unesp.br; murilo.negreli@grad.itapeva.unesp.br; ernofriedmann@hotmail.com

* Corresponding author
} 


\section{INTRODUCTION}

The knowledge of the behavior and the quality assurance of the connection system used in wood structures are very important for the efficiency of the structural system altogether. Among the types of connections used in timber structures, there are for instance metallic pins, connectors, glued connections and the bolts. The steel dowel is composed of by nails, screws and steel bars, while the connectors may be metal rings or metal plates stamped with teeth. The connections constitute the critical point of the timber structures and require experimental studies to assess their real behavior.

When designing joints for steel dowel use in structural elements two failure modes are basically considered: the embedment of the dowel in the wood and the bending of the pin. However, the ABNT NBR 7190:1997 [1] (Brazilian Standard) and the main International Standards, such as, the ASTM D5764:2007 [2] (American Standard) and the EN 383:2007 [3] (European Standard) show different methods for the determination of the embedment strength. The Brazilian Standard [1] defines the embedment strength of a joint as the specific deformation 2\%o. According to the European Standard [3-4] the embedment strength is determined by the force, which causes the displacement of $5 \mathrm{~mm}$ or ultimate load obtained by the specimen. The American Standard [2] uses the force that causes the displacement between the dowel and the timber equal to $5 \%$ of the diameter of the metallic dowel to determine the embedment strength. So, it is observed that the Brazilian Standard [1] uses the specific deformation as a parameter for determining the embedment strength, unlikely the European [3-4] and the American [2] Standards, which use the relative displacement between the dowel steel and the wood. The embedment of the steel dowel in the wood is characterized by the displacement of the joint towards a certain applied force. Contributions to the study of this phenomenon have been conducted for several researchers [5-10] to improve understanding of the timber structure joints. However, despite the growing interest in the study of timber structure joints in Brazil, it is observed that the investigations conducted so far have not produced enough conclusions for a correct analysis of timber structure joints behavior.

The main objective of this research is to evaluate the methods for the determination of the embedment strength for timber based on Brazilian [1] and American [2-11] Standards.

\section{ABNT NBR 7190:1997 "DESIGN OF TIMBER STRUCTURES"}

Experimentally, the Brazilian Standard [1] defines the embedment strength of wood $\left(f_{e}\right)$ as the ratio between the force applied that can cause a residual deformation of $2 \% o\left(F_{e 2 \% o}\right)$ in the joint and the embedding area of the steel dowel in the wood (product between the pin diameter $(d)$ and thickness $(t)$ of the wood piece) in accordance with equation (1).

$$
f_{e} \frac{F_{e 2 \%}}{t \cdot d}
$$

To conduct the embedment test shall be determined an estimated strength from a destructive testing of a twin specimen [1].

Once known the estimated strength, the load should be applied initially in two charge and discharge cycles (with speed of $10 \mathrm{MPa} / \mathrm{min}$ ), ranging from $10 \%$ and $50 \%$ of the estimated value for the load of rupture. Then, the third and final cycle is applied until the final break. In this case, according to the ABNT NBR 7190:1997 [1], the rupture load applied corresponds to the force capable of causing a residual deformation of $2 \% o$ in the joint. Figure 1 illustrates

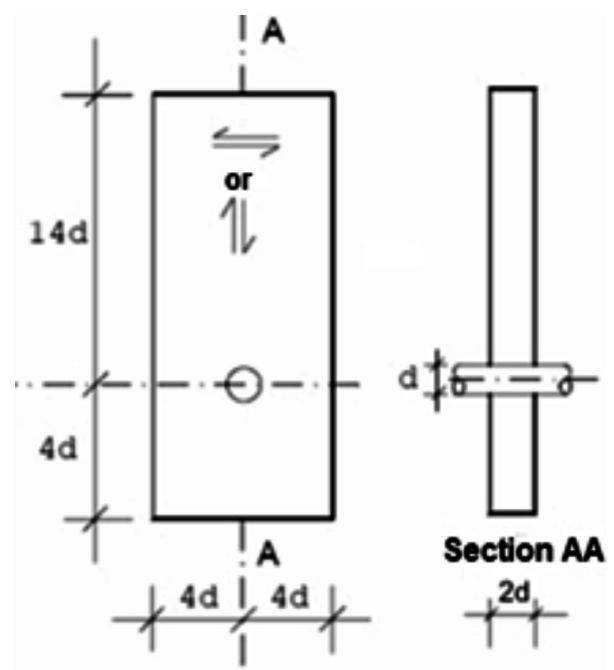

Figure 1. Embedment specimen for tests in parallel and perpendicular directions to the grain [1]. 
the configuration of the specimen and Figure 2 the behavior of the strength curve versus deformation for embedment test according Brazilian Standard [1].

\section{ASTM D5764:2007 'EVALUATING DOWEL- BEARING STRENGTH OF WOOD AND WOOD-BASED PRODUCTS"}

According to the American Standard [2] the embedment strength of the wood is a function of the ratio $5 \%$ of the steel dowel diameter with the area of the specimen where the embedding force occurs, according to equation (2).

$$
f_{e} \frac{F_{e 5}}{t \cdot d}
$$

The experimental procedure recommended by the American Standard [2] does not foresee the estimation of a breaking strength of the specimen for the execution of the loading cycles. The specimen setup for determining the embedment strength for both the parallel direction and the perpendicular directions to the grain is shown in Figure 3, according to the American Standard [2].

Where: A: $\geq$ the highest between $25 \mathrm{~mm}$ or $2 \mathrm{~d}$; B: $\geq$ the highest between $50 \mathrm{~mm}$ or $4 \mathrm{~d}$; $\mathrm{C}: \geq$ the highest between $50 \mathrm{~mm}$ or $4 \mathrm{~d}$; D: $\geq$ the lowest between $38 \mathrm{~mm}$ or $2 \mathrm{~d}$.

The Figure 4 shows the way to obtain the embedment strength from the embedment force

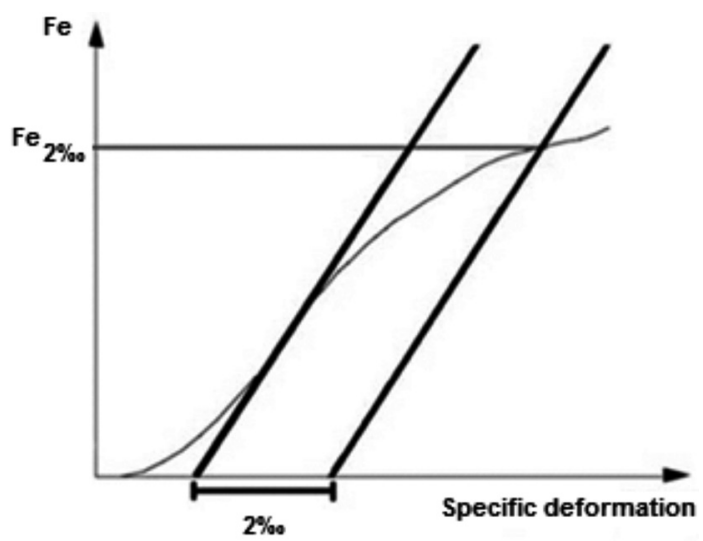

Figure 2. Behavior of the embedment force curve versus specific deformation [1].

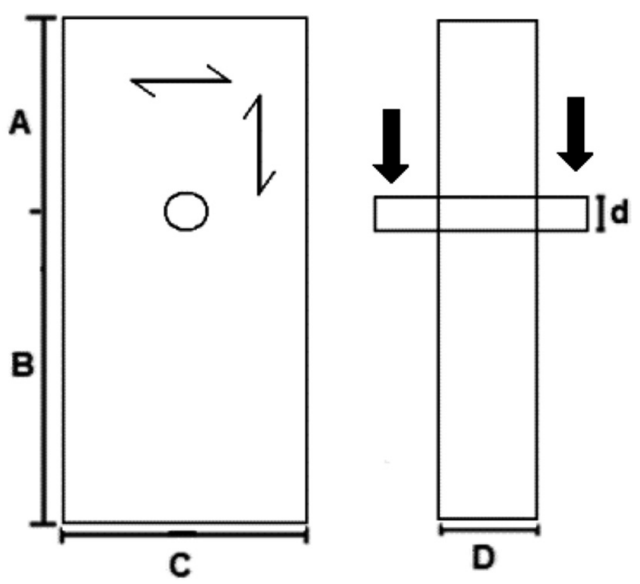

Figure 3. Embedment specimen for testing according to the American Standard [2].

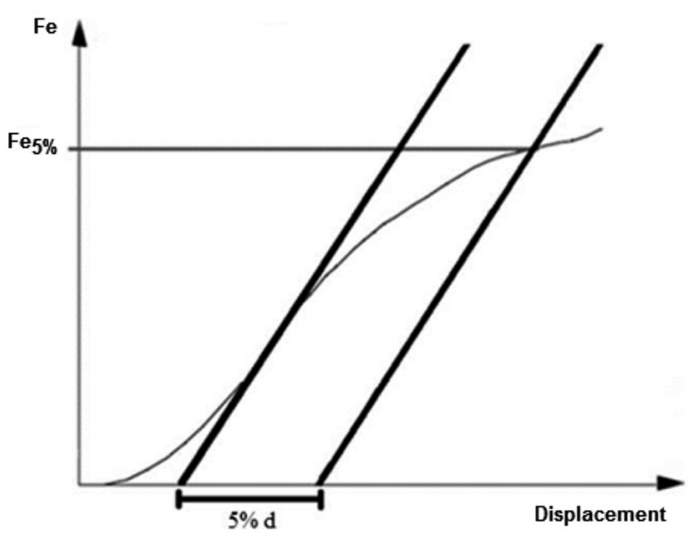

Figure 4. Curve embedment force versus relative displacement [2].

versus deformation diagram using the criteria of the American standard [2].

\section{CALCULATED EMBEDMENT STRENGHT}

The American and Brazilian Standards [2-11] have their specific equations for determining the embedment strength parallel and perpendicular to the grain, and these are listed in Table 1.

Table 1. Equations to calculate the embedment strength according to the norms analyzed.

\begin{tabular}{|c|c|c|}
\hline Standard & $f_{\boldsymbol{e} \mathbf{0}}$ & $f_{\boldsymbol{e q 0}}$ \\
\hline$[1]$ & $f_{e 0}=f_{c 0}$ & $f_{c 90}=0.25 \cdot f_{c 0} \cdot \alpha_{e}$ \\
\hline$[2-11]$ & $f_{e 0}=0.07725 . \rho$ & $f_{c 90}=212 .(0.001 \rho)^{1.45} \cdot d^{-0.5}$ \\
\hline
\end{tabular}


Where:

- $f_{c 0}$ : mean value of compressive strength parallel to the grain $(\mathrm{MPa})$;

- $f_{c 90}$ : mean value of compressive strength perpendicular to the grain (MPa);

- $\alpha e$ : coefficient given as a function of the diameter of the steel dowel by the Brazilian Standard [1];

- $\rho$ : mean values of apparent density $\left(\mathrm{kg} / \mathrm{m}^{3}\right)$;

- $d$ : steel dowel diameter ( $\mathrm{mm})$.

\section{MATERIAL AND METHODS}

In the embedment tests two kinds of reforested timber were used, without any kind of preservative treatment: Pinus elliottii (C30 strength class: compression strength equal to $30 \mathrm{MPa}$ ) and Eucalyptus salligna (C50 strength class: compression strength equal to $50 \mathrm{MPa}$ ). The choice of these species was based on the fact that the coverage of two different strength grades defined by the Brazilian Standard [1] and also on the availability of these species in Itapeva city, São Paulo state, Brazil. To execute the embedment tests on wood specimens common steel bars were used , type 1020, with diameter of $6.35 \mathrm{~mm}$ (1/4") and length of $12 \mathrm{~cm}$. All samples were tested with moisture content of $12 \%$. To conduct the embedment tests a universal testing machine EMIC (DL30000) was used with capacity of $300 \mathrm{kN}$ (30000 kgf), available in the Material Properties Test Laboratory of the São Paulo State University (UNESP), Itapeva Campus, Brazil.

Six replications of specimens (S1-S6) for each species of wood were considered, fiber direction, and specific standard, totaling 48 embedment specimens. To characterize the moisture and the density of the wood as well as the characterization of the steel dowel six replications of the specimens were also used.

\section{DESCRIPTION OF THE EMBEDMENT TESTS}

The dimensions admitted for the specimens according to the recommendations of the Standards [1-2] used in this study are shown in Figures 5 and 6. In the normative situation considered, it was necessary to do more than one load cycle, and so an additional specimen (twin) was made to estimate preliminary embedment strength.

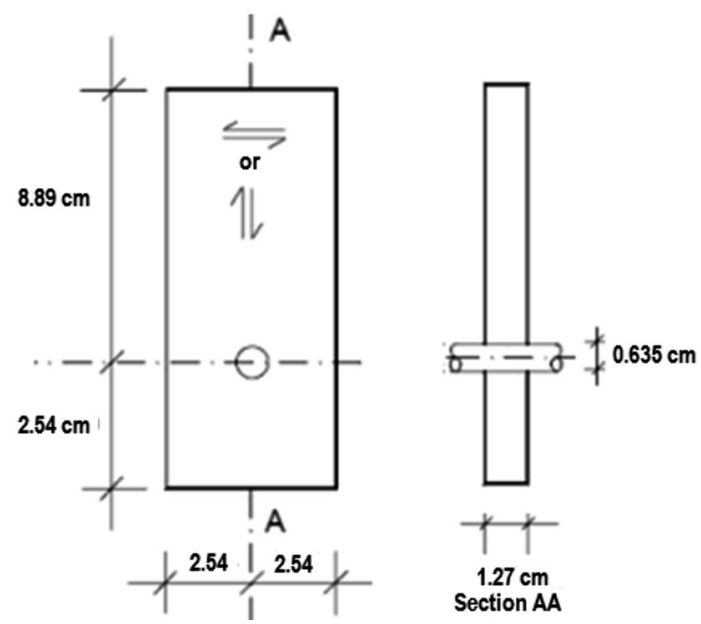

Figure 5. Embedment specimen for testing according to the Brazilian Standard [1].

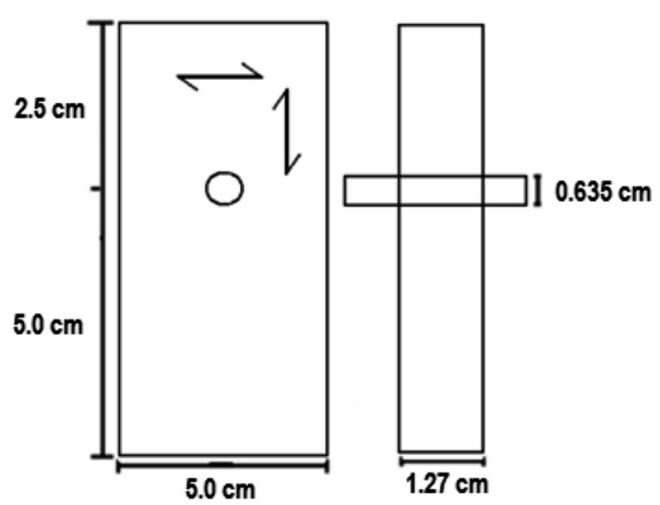

Figure 6. Embedment specimen for testing according to the American Standard [2].

The details of the specimens made for the embedment tests based on each of the Standards [1-2] analyzed in this work are shown in Figure 7.

The load application during the embedment tests was made by the use of Universal Testing Machine EMIC and controlled by a load cell with $100 \mathrm{kN}$ of capacity.

The measurement of the displacement for the specimens of wood was performed by an external displacement transducer of the LVDT (Linear Variable Differential Transformer) type, with a maximum of $10 \mathrm{~mm}$ of travel range.

Figure 8 shows the details of the instrumentation used to obtain the displacements and strain of the 
specimens as well as the details of the embedment tests in the Universal Testing Machine EMIC.

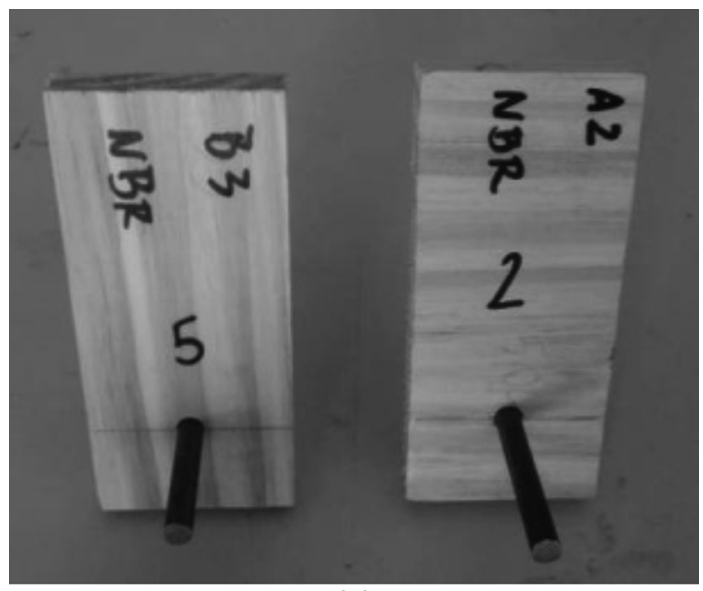

(a)

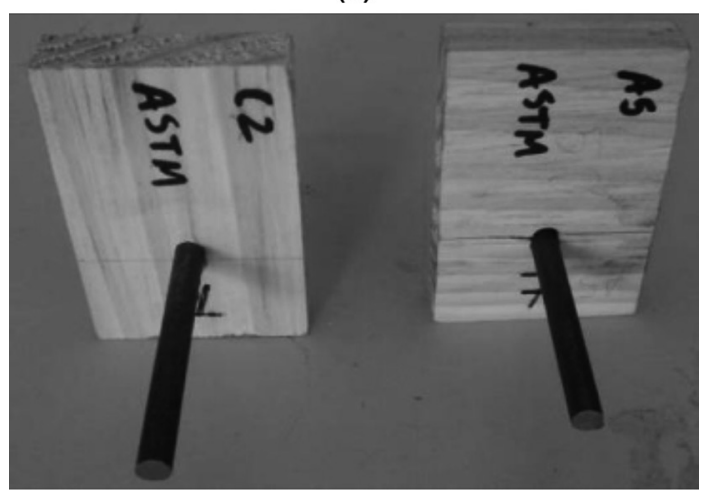

(b)

Figure 7. Details of the specimens for embedment test in the parallel and perpendicular directions to the grain: (a) Brazilian Standard [1]; (b) American Standard [2].

For the analytical calculation of the embedment strength according to equations displaced in Table 1, proposed by the Brazilian Standard [1] and the American Standard [2], it was necessary to characterize the species of wood as well as the steel dowel used in it. For the steel dowel the yield load and the failure load was determined according to Eurocode 5: 2004 and by direct tensile tests.

The parameter $\alpha_{e}$ used to calculate the embedment strength in the perpendicular direction to the grain, according to the Brazilian Standard [1], is determined based on the diameter of the steel dowel. For the

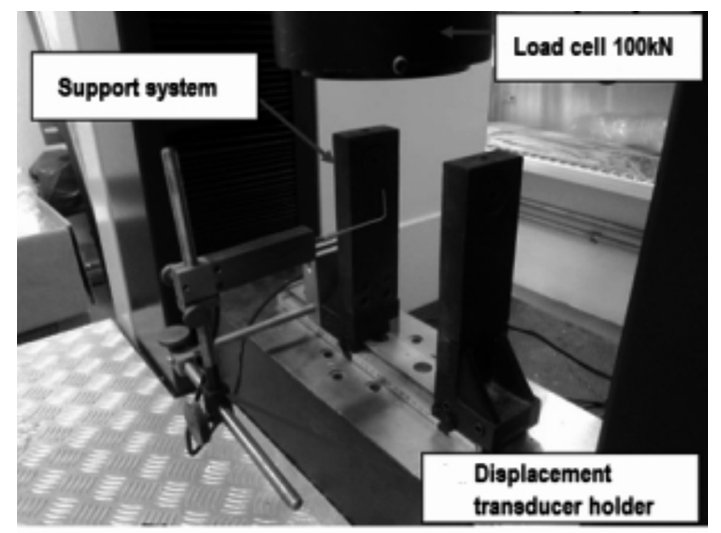

(a)

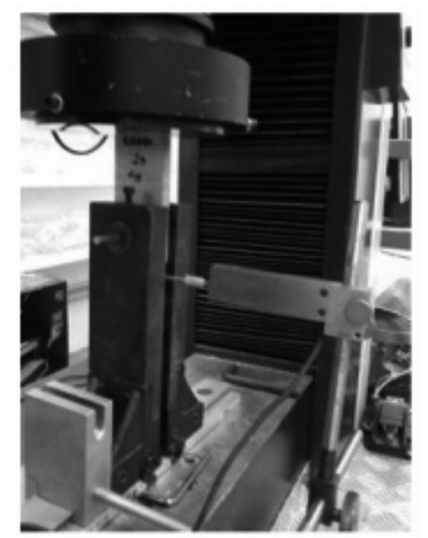

(b)

Figure 8. Embedment test using the EMIC machine:

(a) Embedment test instrumentation;

(b) Conduction of the embedment test.

intermediate diameters values to tabulated ones, $\alpha_{e}$ is determined by linear interpolation. For the steel dowel used in this work with a diameter of $6.35 \mathrm{~mm}$ (1/4") the $\alpha_{e}$ value used was 2.52 , and this value was obtained by linear interpolation according to the Brazilian Standard [1].

The mechanical properties determined for the woods (Pinus elliottii and Eucalyptus salligna) were the compression strength parallel to the grain $\left(f_{c 0}\right)$, the modulus of elasticity in compression parallel to the grain $\left(E_{c 0}\right)$, and the shear strength parallel to the grain $\left(f_{v 0}\right)$. The physical properties of wood determined were the apparent density $\left(\rho_{a p}\right)$ and the moisture content $(\mathrm{U} \%)$. To calculate the embedment strength in the parallel direction to the grain was used according to the Brazilian Standard [1] the average values of the compressive 
strength parallel to the grain were used, these were determined with the characterization of the woods. For the calculation of the analytical values of the embedment strength according to the American Standard [2] were admitted the average values of apparent density $\left(\rho_{a p}\right)$ of the woods.

\section{RESULTS}

Initially, it will be displaced the results of the characterization of the steel and the wood materials, and then, the results of the embedding strength obtained analytically. Tables 2 and 3 show, respectively, the results of mechanical and physical characterization of the woods used $(\mathrm{U}=12 \%)$.

Table 2. Characterization of Eucalyptus salligna at $12 \%$ of moisture content, according to Brazilian Standard [1].

\begin{tabular}{|c|c|c|c|c|}
\hline Specimens & $\begin{array}{c}f_{\boldsymbol{c} \mathbf{0}} \\
(\mathbf{M P a})\end{array}$ & $\begin{array}{c}f_{\boldsymbol{c} \mathbf{9 0}} \\
(\mathbf{M P a})\end{array}$ & $\begin{array}{c}\boldsymbol{f}_{\boldsymbol{v 0}} \\
(\mathbf{M P a})\end{array}$ & $\begin{array}{c}\boldsymbol{E}_{\boldsymbol{c 0}} \\
(\mathbf{M P a})\end{array}$ \\
\hline S1 & 90.52 & 8.90 & 21.78 & 23669 \\
\hline S2 & 60.14 & 7.64 & 17.67 & 16169 \\
\hline S3 & 87.31 & 7.84 & 12.66 & 40330 \\
\hline S4 & 93.54 & 8.03 & 15.15 & 22038 \\
\hline S5 & 65.00 & 8.58 & 18.44 & 31413 \\
\hline S6 & 61.21 & 7.61 & 13.29 & 18849 \\
\hline Mean & 76.29 & 8.10 & 16.50 & 25412 \\
\hline$\sigma$ & 15.73 & 0.52 & 3.46 & 8960 \\
\hline Cv $(\%)$ & 20.62 & 6.52 & 20.98 & 35.26 \\
\hline
\end{tabular}

$\mathrm{Cv}$ : coefficient of variation ( $\sigma /$ mean).

$\sigma$ : Standard deviation.

Table 3. Characterization of Pinus elliotti at 12\% of moisture content, according to Brazilian Standard [1].

\begin{tabular}{|c|c|c|r|c|}
\hline Specimens & $\begin{array}{c}\mathbf{f}_{\mathbf{c 0}} \\
(\mathbf{M P a})\end{array}$ & $\begin{array}{c}\mathbf{f}_{\mathbf{c 9 0}} \\
(\mathbf{M P a})\end{array}$ & $\begin{array}{c}\mathbf{f}_{\mathbf{v} 0} \\
(\mathbf{M P a})\end{array}$ & $\begin{array}{c}\mathbf{E}_{\mathbf{c 0}} \\
(\mathbf{M P a})\end{array}$ \\
\hline S1 & 45.09 & 4.34 & 10.80 & 15092 \\
\hline S2 & 39.32 & 2.91 & 11.89 & 18869 \\
\hline S3 & 49.01 & 4.45 & 9.20 & 21735 \\
\hline S4 & 51.45 & 4.42 & 7.09 & 17040 \\
\hline S5 & 41.87 & 4.80 & 13.13 & 19833 \\
\hline S6 & 40.83 & 4.68 & 8.48 & 13522 \\
\hline Mean & 44.59 & 4.27 & 10.10 & 17682 \\
\hline$\sigma$ & 4.82 & 0.69 & 2.25 & 3062 \\
\hline Cv (\%) & 10.81 & 16.10 & 22.31 & 17.32 \\
\hline
\end{tabular}

Table 4 shows a comparison between the average embedment strength $\left(f_{e}\right)$ values, obtained experimentally in the parallel $\left(0^{\circ}\right)$ and perpendicular $\left(90^{\circ}\right)$ directions to the grain, with the embedding strength values calculated analytically according to the Brazilian [1] and American [2] Standards.

Table 4. Comparison between the analytical and the experimental values of embedment strength achieved at $12 \%$ of moisture content.

\begin{tabular}{|c|c|c|c|c|c|}
\hline \multirow{4}{*}{ Standard } & \multirow{3}{*}{ Dir. } & \multicolumn{4}{|c|}{$f_{e}(\mathrm{MPa})$} \\
\cline { 3 - 6 } & & $\begin{array}{c}\text { Eucalyptus } \\
\text { salligna }\end{array}$ & \multicolumn{2}{c|}{ Pinus elliotti } \\
\cline { 3 - 6 } & & Exp. & Anal. & Exp. & Anal. \\
\hline \multirow{2}{*}[1]{} & $0^{\circ}$ & 49.30 & 78.38 & 29.36 & 44.57 \\
\cline { 2 - 6 } & $90^{\circ}$ & 20.34 & 48.60 & 19.36 & 27.63 \\
\hline \multirow{2}{*}[2]{} & $0^{\circ}$ & 51.89 & 64.45 & 47.61 & 41.28 \\
\cline { 2 - 6 } & $90^{\circ}$ & 43.90 & 59.46 & 26.50 & 27.85 \\
\hline
\end{tabular}

Dir.: Direction in relation to the grain;

Exp.: Experimental values of embedment strength; Anal.: Analytical values of embedment strength.

It was observed that the average values of the experimental embedment strength were relatively smaller than the resistance of the analytical values for both Standards [1-2]. However, for the parallel direction to the grain according to the American Standard [2], the average experimental value obtained was smaller than the analytical value calculated. Furthermore, the biggest proximity between the analytical and experimental values was observed for the American Standard [2]. For the Eucalyptus salligna the differences between the analytical and experimental values for embedment strength was $23.44 \%$ for the Americana Standard [2] and $47.62 \%$ for the Brazilian Standard [1]. On the other hand, for Pinus elliottii the differences between these values were $9.08 \%$ for the American Standard [2] and $32.03 \%$ for the Brazilian Standard [1]. The value of the compressive strength in the parallel direction to the grain used, as an estimation of the embedment standard according to the Brazilian Standard [1], is not a good agreement. The 
experimental method adopted by the Brazilian Standard [1] leads to underestimate the values of the embedment strength. Furthermore, the limit established in function of the residual specific deformation $2 \%$ has a little relevance to determine the embedment strength, in order that, the stress versus specific deformation curve behavior does not have a clear limit of proportionality. The embedment tests performed according to the recommendations of the American Standard [2] indicated the occurrence of bending of the steel dowel in the parallel and perpendicular direction to the grain of Eucalyptus salligna, as well as in the parallel direction to the grain of Pinus elliotti. In the perpendicular direction to the grain of Pinus elliotti the tests according to the
American Standard [2] indicated the occurrence of embedment of the steel dowel in the wood. The embedment tests executed according to the recommendations of the Brazilian Standard [1] indicated the occurrence of embedment of the steel dowel in the parallel and perpendicular directions to the grain of Pinus elliottii, as well as in the perpendicular direction to the grain of Eucalyptus salligna. In the parallel direction to the grain of Eucalyptus salligna, the tests indicated the occurrence of bending of the steel dowel. The behavior of the curves, which correlates the forces applied in the specimens of embedment until the limits of displacement or the deformation established by each of the norms analyzed [1-2], are shown in Figures 9-12.

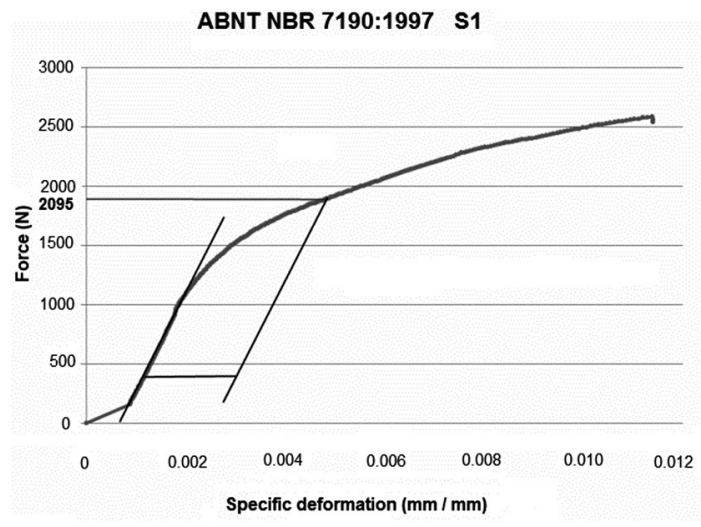

(a)

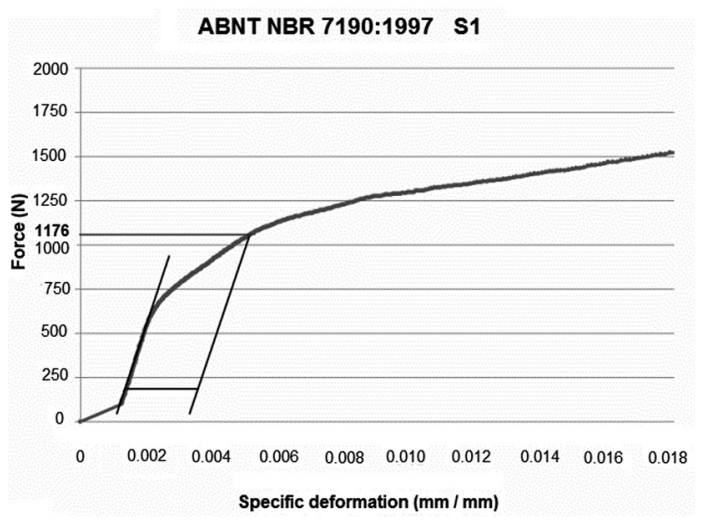

(b)

Figure 9. Curve Embedment force x Specific deformation of Pinus elliotti [1]: (a) Parallel to the grain; (b) Perpendicular to the grain.

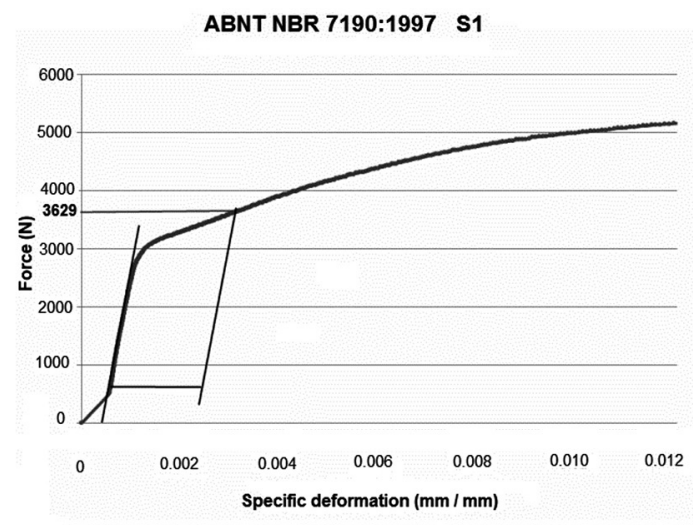

(a)

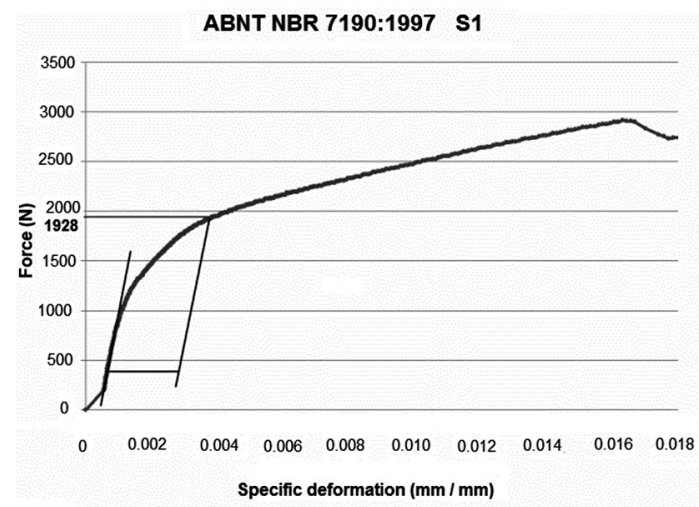

(b)

Figure 10. Curve Embedment force x Specific deformation of Eucalyptus salligna [1]: (a) Parallel to the grain; (b) Perpendicular to the grain. 


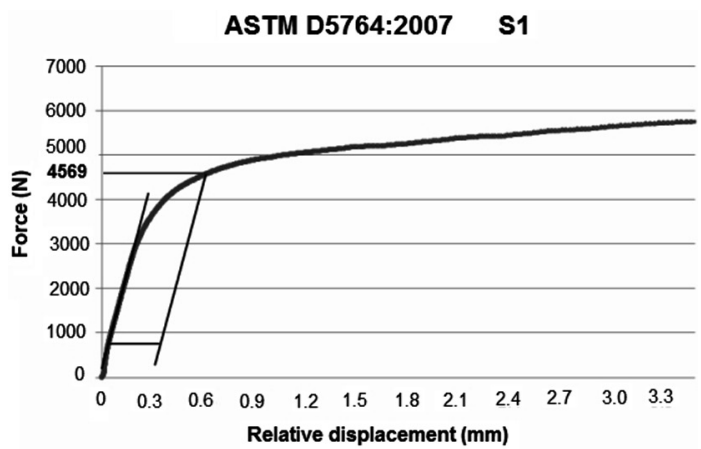

(a)

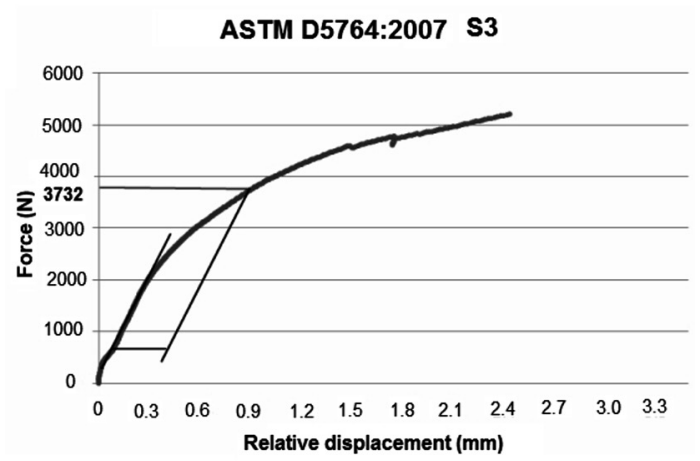

(b)

Figure 11. Curve Embedment force $\mathrm{x}$ Relative displacement of Eucalyptus salligna [2]: (a) Parallel to the grain; (b) Perpendicular to the grain.

\section{CONCLUSIONS}

For both species of wood Eucalyptus salligna and Pinus elliotti the highest mean values of embedment strength were obtained by the experimental methodology proposed by the American Standard [2]

This is due to the Brazilian Standard [1], which uses a graphical method leading to lower values of embedment strength when it is compared with methodology of the American Standard [2].

The analytical and experimental results obtained for both analyzed Standards [1-2], for specimens of Pinus elliottii and Eucalyptus salligna tested with steel dowel of $6.35 \mathrm{~mm}$, showed significant differences when compared to each other values.

These differences may be attributed in part to the influence of the bending effect of the steel dowel

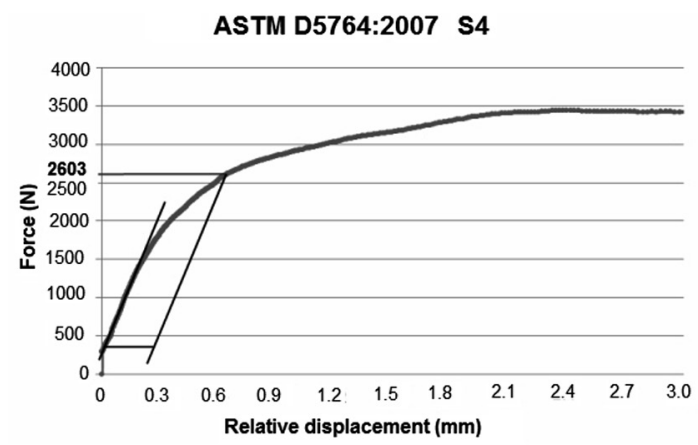

(a)

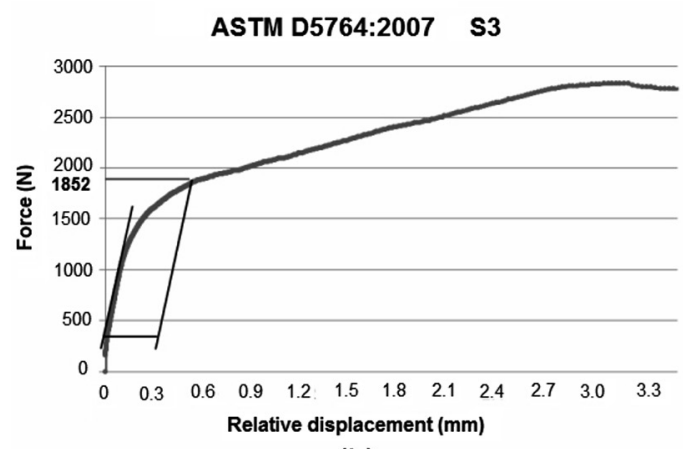

(b)

Figure 12. Curve Embedment force x Relative displacement of Pinus elliotti [2]: (a) Parallel to the grain; (b) Perpendicular to the grain.

associated to its embedment in the wood in the final response of the experimental test.

For it was opted to use a more flexible steel dowel as the starting point of this research. In this context, it is highlighted the relevance of the recommendation of the Brazilian Standard [1] to use steel dowel with diameters equal or greater than $10 \mathrm{~mm}$. Thus, it is expected that the experimental test be conditioned by embedment of the steel dowel in the wood so the bending of the steel dowel does not occur.

The use of the force that causes the residual displacement equal to $5 \%$ in relation to the diameter of the steel dowel, as a criterion to determine the wood's embedment strength by the American Standard [2], showed being more appropriate by the criterion adopted by the Brazilian Standard [1]. 
For Pinus elliottii, for which the bending of the steel dowel had a lower influence on the answer, the analytical and experimental results were closer to each other when they are compared to the results of the Eucalyptus salligna, where the bending of the steel dowel had greater influence on the final results.

For a more definitive conclusion about the best test method, there is still the need for additional embedment tests to consider the steel dowel with a larger diameter.

Another strategy of analysis is to keep the diameter of the steel dowel of $6.35 \mathrm{~mm}$ and then, consider a steel dowel with higher values of yield stress. For instance nails, which have yield stress around $600 \mathrm{MPa}$ rather than steel 1020 that has around $384.82 \mathrm{MPa}$ of yield stress, which was used in this study.

\section{ACKNOWLEDGEMENTS}

The authors gratefully acknowledge the financial support of FUNDUNESP for this research.

\section{REFERENCES}

[1] Associação brasileira de normas técnicas NBR 7190. "Projeto de estruturas de madeira". ABNT. Rio de Janeiro, Brasil. 1997.

[2] American society for testing and materials D5764. "Evaluating dowel-bearing strength of wood and wood-based products". ASTM. West Conshohocken, United States. 2007.

[3] European committee for standardization - EN 383. "Timber structures: Test methods Determination of embedding strength and foundation values for dowel type fasteners". EN. Brussels, Belgium. 2007.
[4] European committee for standardization - EUROCODE 5 - Part 1-1. "Design of timber structures: General rules and rules for buildings". CEN. Brussels, Belgium. 2004.

[5] M.A.M. Oliveira and A.A. Dias. "Ligações com Pinos Metálicos em Estruturas de Madeira". Caderno de Engenharia de Estruturas. Vol. $7 \mathrm{~N}^{\circ}$ 26, pp. 33-64. 2005.

[6] G.C. Stamato and C. Calil Junior. "Resistência ao Embutimento da Madeira Compensada". Caderno de Engenharia de Estruturas. Vol. 1 $\mathrm{N}^{\circ} 18$, pp. 49-76. 2002.

[7] I.G.B. Stevanović and T.K. Mišulić. "Embedment Test of Wood for Dowel-Type Fasteners". Wood Research. Vol. 57, Issue 4, pp. 639-650. 2012.

[8] J.C. M. Schoenmakers, A.J.M. Jorissen and A.J.M. Leijten. "Evaluation and Modelling of Perpendicular to Grain Embedment Strength”. Wood Science and Technology. Vol. 44, Issue 4, pp. 579-595. 2010.

[9] D.H. Almeida, F.S. Ferro, L.D. Varanda, A.L. Christoforo, F.A.R. Lahr, J.C. Molina, C. Calil Junior. "Comparação entre valores de ensaios experimentais e calculados da resistência ao embutimento da madeira de Pinus taeda". RevistaArvore. Vol. $38 \mathrm{~N}^{\circ}$ 2, pp. 347-357. 2014.

[10] D.H.Almeida, R.M. Scaliante, A.L. Christoforo, F.A.R. Lahr, J.C. Molina e C. Calil Junior. "Comparação das resistências ao embutimento paralelo às fibras de madeiras de pínus oocarpa, cumaru e pínus taeda". Ambiente Construído, Vol. $14 \mathrm{~N}^{\circ}$ 3, pp. 113-119. 2014.

[11] American national standard for wood products/ american forestand paper association - NDS. "American national design and specification for wood construction". ANSI/AF\&PA. Washington, United States. 2001. 